JURNAL KETAHANAN NASIONAL

Vol. 25, No. 1, April 2019, Hal 1-14

DOI:http://dx.doi.org/ 10.22146/jkn.38265

ISSN:0853-9340 (Print), ISSN:2527-9688 (Online)

Online sejak 28 Desember 2015 di :http://jurnal.ugm.ac.id/JKN

VOLUME 25

No. 1, April 2019

Halaman 1-14

\title{
Kontrol Pemuda Terhadap Tata Kelola Migas Dan Implikasinya Pada Ketahanan Wilayah Di Kawasan Migas Blok Cepu Kabupaten Bojonegoro
}

\author{
Danang Wahyuhono \\ Pusat Pengembangan Kapasitas dan Kerjasama Fisipol Universitas Gadjah Mada \\ email: danang.wahyuhono@gmail.com \\ Suryo Purwono \\ Fakultas Teknik Universitas Gadjah Mada \\ email:spurwono@ugm.ac.id

\section{Dyah Mutiarin} \\ Fakultas Ilmu Sosial dan Ilmu Politik Universitas Muhammadiyah Yogyakarta \\ email:mutiarin@yahoo.com
}

\begin{abstract}
This study aimed to analyzed form and capabilities of youth control, as well as to assessed their implications for regional resilience. Regional resilience was analyzed through the aspect of environmental, economic, social and security resilience, in which they were directly related to the oil and gas project activities in Cepu Block, namely Banyuurip area, Jambaran Tiung Biru area, and Pipe Line area.

This study used qualitative methods, as it seeked to revealed the complex and deep social reality in the Cерu Block area. Using theory of access from Ribbot and Peluso (2003) which emphasized the ability of youth in controlling the flow of benefits and the impact of a resource. Control was defined as the ability to organized and directed relational actions. The flow of benefits and impacts were controlled in the form of employment benefits and Corporate Social Responsibility (CSR) programs, as well as environmental impacts. Youth had bundle of power to strengthened their control in the form of identity and social relations.

This study revealed the diverse realities associated with youth control capabilities, and their implications for regional resilience. The most significant implications were environmental resilience, while economic, social, and security resilience were still vulnerable.
\end{abstract}

Keywords: Youth Control, Oil and Gas Governance, Regional Resilience.

\begin{abstract}
ABSTRAK
Penelitian ini bertujuan mengkaji bentuk dan kemampuan kontrol pemuda, serta implikasinya terhadap ketahanan wilayah. Ketahanan wilayah dikaji dalam gatra ketahanan lingkungan, ekonomi, sosial, dan keamanan.

Penelitian ini menggunakan metode kualitatif, karena berupaya mengungkap realitas sosial yang kompleks dan mendalam di kawasan Blok Cepu. Kontrol pemuda dianalisis menggunakan teori akses dari Ribbot dan Peluso (2003) yang menekankan kemampuan pemuda dalam mengontrol aliran manfaat dan dampak dari suatu sumber daya. Kontrol didefinisikan sebagai kemampuan mengatur dan mengarahkan tindakan relasional. Aliran manfaat dan dampak yang dikontrol berupa manfaat pekerjaan dan program CSR, serta dampak lingkungan. Pemuda menggunakan ikatan kekuatan (bundle of power) untuk memperkuat kontrolnya, terutama berupa identitas dan relasi sosial.
\end{abstract}


Penelitian ini mengungkap realitas yang beragam terkait kemampuan kontrol pemuda, dan implikasinya padaketahanan wilayah. Implikasi yang paling signifikan terdapat pada ketahanan lingkungan, sedangkan ketahanan ekonomi, sosial, dan keamanan masih bersifat rentan.

Kata Kunci: Kontrol Pemuda, Tata Kelola Migas, Ketahanan Wilayah.

\section{PENGANTAR}

Kandungan minyak dan gas bumi (migas) yang melimpah di Kabupaten Bojonegoro memiliki peran penting dalam membangun ketahanan nasional. Blok migas yang telah berproduksi dan terbesar di Bojonegoro ialah Blok Cepu. Blok Cepu diharapkan mampu menyumbang $25 \%$ sampai $30 \%$ pasokan minyak nasional, serta ditarget memenuhi lifting minyak sebesar 825 ribu bph pada APBN-P 2015 (Jati, 2015). Target yang ditetapkan untuk Blok Cepu sebenarnya dipatok terlaksana pada 2014 ketika Blok Cepu mencapai puncak produksi sebesar 165 ribu bph, namun target puncak produksi tersebut tidak terealisasi. Pemerintah Pusat mengeluarkan kebijakan berupa Instruksi Presiden (Inpres) Nomor 2 Tahun 2012 tentang Peningkatan Produksi Minyak Bumi Nasional, termasuk untuk merespon kemunduran puncak produksi Blok Cepu. Inpres ini mengamanatkan bupati/walikota agar: "melakukan percepatan dan kemudahan perizinan yang terkait dengan upaya peningkatan produksi minyak bumi nasional dan memberikan dukungan dan melakukan kebijakan dalam rangka mendukung peningkatan produksi minyak bumi nasional".

Inpres No. 2 Tahun 2012 tidak secara eksplisit menyasar konteks Bojonegoro, namun kebijakan tersebut lahir ketika pemerintah daerah juga mengeluarkan kebijakan yang dianggap Pemerintah Pusat bersifat kontraproduktif dengan proses produksi Blok Cepu. Pemerintah Kabupaten Bojonegoro mengeluarkan kebijakan berupa:
Peraturan Daerah Nomor 23 Tahun 2011 tentang Percepatan Pertumbuhan Ekonomi Daerah Dalam Pelaksanaan Eksplorasi Dan Eksploitasi Serta Pengolahan Minyak Dan Gas Bumi Di Kabupaten Bojonegoro atau sering disebut Perda Konten Lokal. Perda Konten Lokal secara umum berupaya mengadvokasi keterlibatan sumber daya lokal dalam industrialisasi migas.

Berpijak dari realitas di atas, dapat dimaknai bahwa ketahanan nasional dan ketahanan wilayah sangat mungkin dibangun di atas rasionalitas yang berbeda. Rasionalitas yang membangun ketahanan nasional dalam konteks migas Blok Cepu ialah kelancaran produksi migas guna mencapai ketahanan energi nasional dan manfaatnya bagi pendapatan negara, sedangkan ketahanan wilayah di level kabupaten dan secara khusus di desa-desa kawasan Blok Cepu akan terbangun jika kepentingan lokal mampu terlindungi dan terpenuhi.

Ketahanan wilayah penghasil migas nampak sering diuji dengan berbagai persoalan. Masyarakat Blok Cepu menghadapi persoalan berupa perubahan sumber penghidupan yang awalnya pertanian namun tergerus oleh kepentingan migas yang membutuhkan banyak lahan, kontestasi kepentingan antar warga lokal untuk memperebutkan aliran manfaat industrialisasi migas (Huda, 2011), hingga persoalan lingkungan akibat kesalahan flaring atau pembakaran gas suar bakar minyak bumi.

Pemuda menjadi aktor penting di tengah dinamika tersebut. Mereka berposisi 
sebagai penerima dampak maupun sebagai aktor aktif yang menyuarakan berbagai kepentingan masyarakat lokal. Ratusan pemuda lokal menjadi penerima dampak sebagai pengangguran ketika proyek EPC berakhir. Pemuda juga menjadi aktor aktif, misalnya melalui organisasi Karang Taruna untuk menggerakkan tuntutan warga. Pemuda pernah mengorganisir warga Desa Mojodelik dalam dua kali demonstrasi menuntut tanggung jawab ExxonMobil Mobil Cepu Limited (EMCL) untuk memberikan kompensasi yang layak bagi warga akibat dampak flare. Pemuda juga menjadi penerima aliran manfaat berupa program tanggung jawab sosial perusahaan (TJSP)/Coorporate Social Responsibilty (CSR) dari perusahaan migas.

Konteks tata kelola migas di Bojonegoro secara normatif telah mengadvokasi dan melibatkan masyarakat untuk menerima dan mengontrol aliran manfaat migas. Hal itu termanifestasikan dalam Perda Konten Lokal, Perda ADD, Perda Transparansi Tata Kelola Migas, dan Perda CSR/TJSP. Bupati Bojonegoro, Suyoto berpandangan bahwa adanya aliran manfaat yang berdampak positif bagi masyarakat akan menjaga stabilitas keamanan wilayah.

Merujuk telaah kritis dari Ribbot dan Pelusso (2003: 153-181), adanya instrumen tata kelola tersebut tidak selalu linier dengan upaya pemenuhan kepentingan lokal. Ia berpandangan bahwa aliran manfaat dari sumber daya bukan berbasis klaim atau merupakan hak yang mudah dinikmati, melainkan bertumpu pada kemampuan dan kapasitas pemangku kepentingan, termasuk pemuda untuk memperoleh, mengontrol hingga menjaganya. Penelitian ini mengkaji kontrol pemuda di kawasan migas Blok Cepu atas berbagai aliran manfaat dan dampak dari industrialisasi migas dalam ruang tata kelola migas yang berlangsung di Bojonegoro.

Teori akses dari Ribbot dan Peluso (2003) menjabarkan akses ke dalam tiga hal, yaitu kemampuan memperoleh, mengontrol, dan memelihara akses. Kontrol akses didefinisikan sebagai kekuataan untuk mengarahkan dan mengatur tindakan, sedangkan kemampuan memelihara akses adalah upaya mencurahkan kemampuan agar akses terhadap sumber daya tetap terbuka.

Akses terhadap sumber daya yang digagas oleh teori ini tidak terbatas pada objek materialnya, melainkan aliran manfaat dari sumber daya tersebut. Akses terhadap aliran manfaat memiliki 8 (delapan) mekanisme struktural dan relasional yang dapat menjadi ikatan atau jaringan kekuatan (bundle of power) untuk memperoleh, mengontrol dan memelihara akses. Delapan ikatan kekuatan tersebut adalah akses terhadap teknologi, modal, pasar, tenaga dan kesempatan kerja, pengetahuan, otoritas, identitas sosial, dan relasi sosial.

Berkembangnya wacana tentang kontrol warga relevan dengan perubahan konteks sosial berupa demokratisasi dan governance. Adanya perubahan konteks ruang relasi menjadi governance dan didorong demokratisasi di berbagai bidang, membuat kajian kepemudaan juga banyak memberikan konsep tentang keterlibatan atau partisipasi pemuda dalam proses politik pengambilan keputusan. Pemuda tidak semata menjadi kelompok yang terkontrol, namun menjadi agen pengontrol sosial. World Youth Report (2003: 280) menngkonsep partisipasi pemuda sebagai derajat kontrol dan kekuasaan yang ditransfer kepada pemuda. Berbagai model partisipasi pemuda juga dijabarkan dalam laporan tersebut, yaitu dalam bentuk penelitian 
investigatif terkait isu kepemudaan; upaya pemuda untuk mendesain, menjalankan, dan monitoring-evaluasi program; menjalankan peran representasi dan advokasi sosial; melakukan analisis kebijakan dan pembangunan; melakukan kampanye dan lobi terkaik hak dan kekhawatiran pemuda; pengembangan dan pengelolaan organisasi kepemudaan; partisipasi melalui media masa; partisipasi di dalam konfrensi nasional dan internasional; hingga terlibat dalam struktur demokrasi politik yang sejajar dengan orang dewasa dalam mempengaruhi agenda sosial, ekonomi, dan politik melalui dewan atau parlemen muda.

Menurut Walker, dkk (2014: 2-3), partisipasi pemuda merupakan bagian dari participatory governance sebagai strategi tata kelola yang mengacu pada proses keterlibatan aktif warga negara dalam membahas distribusi sumber daya publik dan pengambilan keputusan di dalamnya. Partisipasi pemuda dalam hal ini terkait dengan cara pemuda menyuarakan pandangan, kekhawatiran, dan hak-hak mereka, serta keterlibatan dalam dialog dan pengambilan keputusan yang berpengaruh bagi pemuda, termasuk cara pemuda melibatkan diri sebagai masyarakat aktif.

Adanya kontrol pemuda terhadap tata kelola migas merupakan upaya untuk mempengaruhi keberadaan sumber daya alam agar memberi manfaat bagi ketahanan wilayah. Keberadaan sumber daya alam di sisi lain juga menjadi determinan berbagai realitas negatif seperti ketimpangan sosial dan konflik, atau sering disebut paradox of plenty (Humphreys, Sachs, dan Stiglitz, 2007). Adanya paradoks keberlimpahan yang dapat berdampak pada masyarakat sekitar sumur migas, maka Ross (2007) merumuskan beberapa kebijakan tata kelola migas, yakni distribusi pendapatan secara langsung, pemberian insentif pada perusahaan untuk memperkerjakan tenaga lokal, membatasi migrasi tenaga kerja dari luar, mendorong perusahaan berinvestasi pada pembangunan lokal, dan menjadikan LSM sebagai mediator.

Sumber daya alam tidak semata menjadi modal dasar bagi ketahanan, namun dapat pula mendatangkan Ancaman, Gangguan, Hambatan, dan Tantangan (AGHT) bagi ketahanan. Rumusan ketahanan yang menekankan ketangguhan dan keuletan guna menghadapi AGHT (Sunardi, 1997: 2) sebangun dengan rumusan ketahanan dari para sarjana luar negeri yang secara umum merumuskan konsep ketahanan berdasarkan dimensi sosial dan ekologi. Ketahanan dilihat memiliki posisi penting di tengah perubahan, guncangan, ketidakpastian dan tekanan baik yang berasal dari faktor ekologis seperti perubahan iklim dan menurunnya daya dukung ekosistem, maupun dari faktor sosial misalnya persoalan ekonomi dan konflik sosial (Magis, 2010; Boyd dan Folke, 2012; Berkes dan Ross, 2013; Bhamra, 2015).

\section{PEMBAHASAN}

\section{Gambaran Umum Kabupaten Bojonegoro Dan Blok Cepu}

Kabupaten Bojonegoro terletak di Provinsi Jawa Timur bagian barat yang berbatasan langsung dengan Provinsi Jawa Tengah. Daerah ini berjarak sekitar 110 km dari Kota Surabaya sebagai ibu kota provinsi. Kabupaten Bojonegoro secara keseluruhan memiliki luas wilayah sebesar $2.198,79 \mathrm{~km}^{2}$ atau menempati $4,60 \%$ dari luas wilayah Provinsi Jawa Timur.

Bojonegoro diberikan karunia sumur dan blok migas di berbagai penjuru wilayah, dengan blok migas yang terbesar adalah 
Danang Wahyuhono, Suryo Purwono, Dyah Mutiarin -- Kontrol Pemuda Terhadap Tata Kelola Migas Dan Implikasinya Pada Ketahanan Wilayah Di Kawasan Migas Blok Cepu Kabupaten Bojonegoro

Gambar 1

Peta Sebaran Blok Migas di Kabupaten Bojonegoro

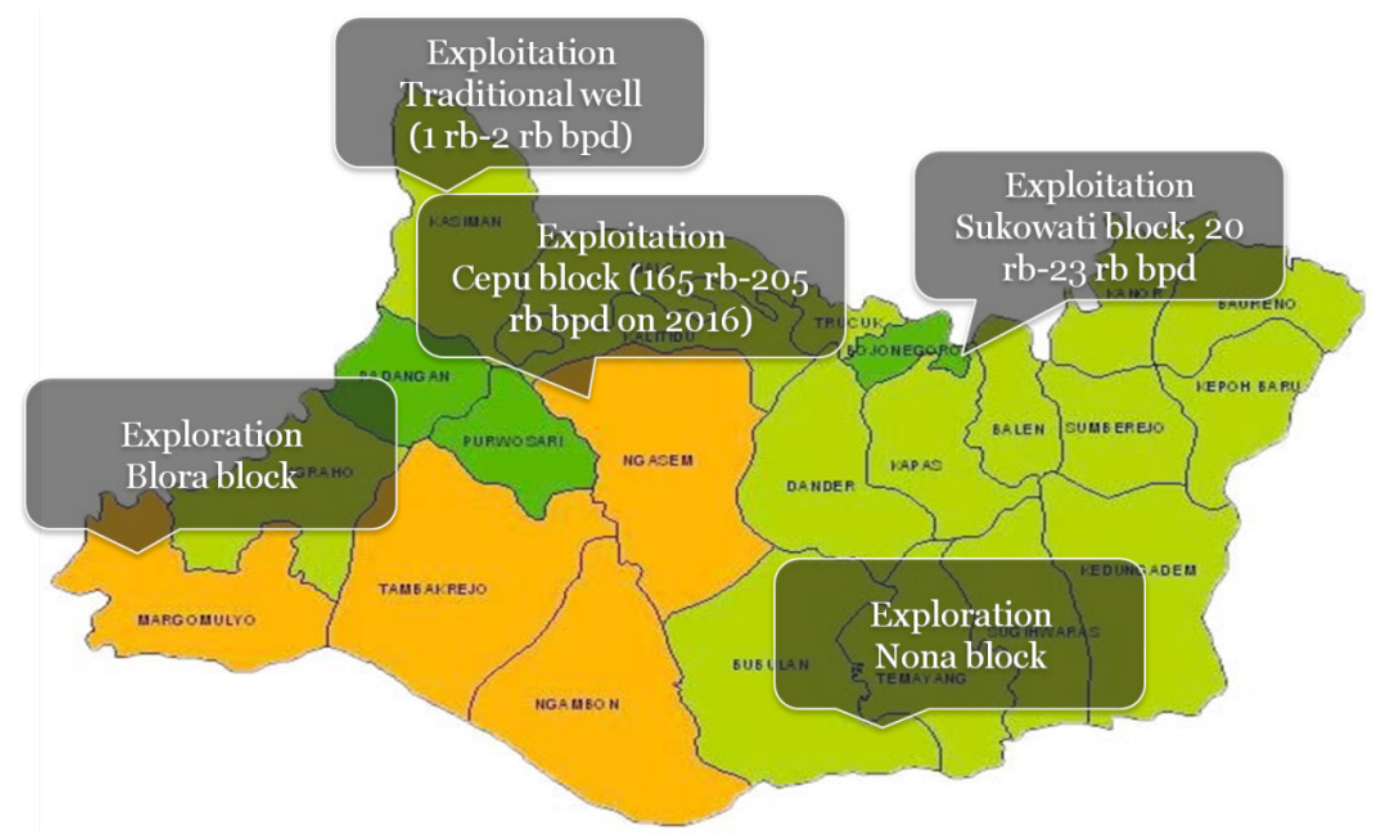

Sumber: Bojonegoro Institute, 2016

Blok Cepu. Cepu selama ini identik dengan Kabupaten Blora sebagai wilayah yang secara administratif berada di dalamnya, namun manfaat sekaligus dampak pertambangan Blok Cepu lebih banyak diterima oleh Kabupaten Bojonegoro. Blok Cepu terletak di dua kabupaten bertetangga yang berbeda provinsi tersebut. Letak yang berada di dua wilayah tidak otomatis membuat aliran manfaat Blok Cepu terbagi rata bagi keduanya. Salah satu aliran manfaat yang menimbulkan kecemburuan adalah Dana Bagi Hasil (DBH). Kabupaten Blora belum menerima DBH dari pemerintah pusat hingga 2016. Aliran DBH mengikuti mulut sumur yang terletak di wilayah Bojonegoro (Radar Bojonegoro, 2016). Kawasan Blok Cepu di wilayah Kabupaten Bojonegoro merentang di berbagai kecamatan, yaitu Gayam, Ngasem, Kalitidu, Tambakrejo, Purwosari, dan Padangan. Gayam merupakan kecamatan termuda di Bojonegoro yang menjadi sentra aktivitas pertambangan karena keberadaan Sumur Banyuurip.

\section{Kontrol Pemuda Terhadap Tata Kelola Migas}

Implementasi kebijakan tata kelola migas terjalin dengan dinamika pelaksanaan proyek Blok Cepu. Jalinan tersebut telah memunculkan aliran manfaat dan dampak, misalnya manfaat pekerjaan sekaligus dampak pengangguran ketika pekerjaan berakhir. Adanya aliran manfaat dan dampak tersebut, memantik ruang kontrol bagi pemuda. Kontrol pemuda tidak hanya terhadap akses pekerjaan, namun juga aliran manfaat lain berupa CSR serta adanya dampak lingkungan.

Kontrol terhadap akses pekerjaan sempat membawa hasil dan dinikmati pemuda, terutama ketika proyek EPC atau konstruksi pra produksi berlangsung. Terdapat 1.791 masyarakat Blok Cepu yang terserap menjadi pekerja pada proyek EPC 1, namun dengan sebagian besar spesifikasinya adalah pekerja unskill atau kasar. Kehadiran ribuan pekerja proyek berdampak pada aktivitas ekonomi yang tinggi di kawasan tersebut. Proyek EPC 
sekaligus membawa dampak multi ganda (multiplier effect) bagi masyarakat kawasan Blok Cepu maupun Bojonegoro secara umum. Banyak masyarakat Blok Cepu yang mendirikan warung di sekitar kawasan proyek. Para pekerja semakin ramai mendatangi warung kopi dan biliar ketika malam minggu atau selepas mereka menerima gaji.

Riuhnya suasana proyek EPC tidak berlangsung lama. Proyek ini memiliki batas waktu agar puncak produksi Blok Cepu segera terlaksana. Pengurangan pekerja terjadi, terutama memasuki tahun 2015. Community Affair dan Manajer PT. Tripatra Budi Karyawan menyatakan bahwa pihaknya telah berupaya memaksimalkan tenaga kerja lokal dalam proyek EPC, namun jika pengerjaan di lapangan telah selesai maka para pekerja juga harus diberhentikan. Pemberhentian terutama menyasar tenaga kerja luar daerah, namun juga tidak sedikit tenaga kerja lokal yang tidak diperpanjang kontraknya, karena persoalan kompetensi dan pelanggaran etika kerja (Tabloid Blok Bojonegoro Edisi Februari 2015).

Tabel 1

Jumlah Tenaga Kerja EPC 1 Sejak Pertengahan 2014

\begin{tabular}{cc}
\hline Bulan & Jumlah \\
\hline Juli & 6.703 \\
Agustus & 7.638 \\
September & 8.546 \\
Oktober & 9.066 \\
November & 11.312 \\
Desember & 10.232 \\
Januari & 8.238 \\
\hline
\end{tabular}

Sumber: Tabloid Blok Bojonegoro Edisi Februari 2015 dan Disnakertransos/Disperinaker Kab. Bojonegoro, 2015

Harapan pemuda tidak beranjak pada sektor migas, meskipun proyek EPC telah berakhir. Pemuda melihat potensi proyek yang tidak kalah besar dari proyek EPC Blok
Cepu akan berlangsung. Proyek itu adalah pengerjaan Gas Processing Facility (GPF) Sumur Jambaran Tiung Biru (J-TB) yang juga masuk kawasan Blok Cepu. Mantan pekerja EPC yang masih bergantung pada pekerjaan di proyek migas bisa dikatakan berada dalam masa penantian. Masa penantian itu telah berlangsung sekitar 1 tahun dan dimanfaatkan untuk aktif mencari informasi lowongan pekerjaan pada kepala desa. Kepala desa dan pemuda di wilayah Kecamatan Gayam tidak memiliki posisi sekuat ketika proyek EPC Banyuurip, karena proyek ini berada di luar wilayahnya, yaitu di Kecamatan Ngasem. Persoalan identitas kewilayahan ini mulai dikhawatirkan oleh pemuda.

Pemuda Desa Bandungrejo merupakan pihak yang lebih dapat mengakses pekerjaan proyek J-TB. Sopri merupakan salah seorang pemuda Desa Bandungrejo yang berhasil mengakses pekerjaan di tahap awal proyek GPF J-TB. Ia merasa beruntung karena memiliki akses pada Mbah Wo Wanuri seorang kontraktor desanya yang memegang kontrol atas akses pekerjaan pada proyek J-TB.

"Banyak alumni EPC yang ingin masuk sini, banyak yang ke Mbah Wo. Sebelumnya distop dulu, sebelum dari desa sendiri kalau sudah kerja semua, baru dari luar masuk. Nanti pekerjaan kayak operator, manajer, disaring dulu se-Bandungrejo. Ga ada yang mampu baru dari luar, tapi kalau ada yang mampu tetap Bandungrejo dulu" (Wawancara Sopri, pemuda Desa Bandungrejo/pekerja proyek GPF J-TB, 28 Maret 2017).

Mengikuti alur teoritis tentang kontrol akses dari Ribbot dan Peluso (2003), maka Perda Konten Lokal dijadikan alat untuk menegaskan akses terhadap identitas sosial. Akses terhadap identitas sosial misalnya berbasis agama, suku, jenis kelamin dan 
tempat lahir. Hal ini dijadikan instrumen inklusi atau eksklusi bagi pihak tertentu untuk memperoleh, mengontrol, dan memelihara akses terhadap sumber daya. Kelompok masyarakat, termasuk pemuda yang menyatakan diri paling lokal, setidaknya telah berupaya mengarahkan tindakan kelompok lain dari luar komunitasnya atau luar desa untuk tidak terlalu berharap terlebih dahulu pada akses aliran manfaat pekerjaan yang tersedia. Pekerjaan diakses terlebih dahulu oleh pemuda yang wilayahnya menjadi tempat berlangsungnya proyek.

Program CSR merupakan aliran manfaat dari aktivitas proyek migas Blok Cepu, selain manfaat berupa pekerjaan. CSR perusahaan migas sebagian besar dikucurkan oleh EMCL selaku operator sumur Banyuurip. Beberapa program CSR secara eksplisit menyasar pada kelompok pemuda, yaitu berupa program kewirausahaan dan pelestarian lingkungan hidup. Program CSR menjadi salah satu cara agar masyarakat tidak terlalu tergantung pada pekerjaan proyek migas. Pengembangan kewirausahaan melalui CSR sebagai cara alih profesi dari pekerja proyek migas menjadi pekerja non-migas.

Upaya alih profesi menjadi wirausaha telah direspon oleh pemuda Desa Begadon Kecamatan Gayam. Pemuda desa yang tergabung dalam karang taruna menginisiasi usaha budidaya jamur dan pembuatan olahan berbahan jamur. Ide itu awalnya dijalankan sendiri oleh karang taruna secara gotong royong, misalnya dalam pembuatan tempat budidaya, kemudian diajukan pada EMCL untuk memperoleh bantuan bibit jamur dan pendampingan.

Tidak semua program CSR yang menyasar pemuda berangkat dari ide pemuda sendiri. Ide itu ada yang berawal dari LSM dan perusahaan, kemudian pemuda menjadi kelompok sasaran pelaksanaan program. Hal ini terjadi di desa kawasan jalur pipa minyak bumi. Program Usaha Ekonomi Produktif (UEP) bagi karang taruna di kawasan tersebut muncul atas ide LSM yang kemudian sejalan dengan ide perusahaan agar pemuda terlibat dalam pengamanan jalur pipa minyak.

Bentuk kontrol pemuda terhadap aliran CSR ini berbeda dengan kontrol terhadap akses pekerjaan, dimana faktor identitas sosial sebagai pihak yang paling lokal tidak digunakan oleh pemuda. Pemuda di kawasan Sumur Banyuurip, Jambaran, dan Jalur Pipa, seluruhnya mendapatkan aliran CSR, meskipun demikian terdapat perbedaan dari cara memperolehnya dan sikap pemuda ketika menjalankan program CSR di masing-masing kawasan. Pemuda di kawasan Sumur Banyuurip telah mempersiapkan diri sebelum mendapatkan program CSR, sehingga memperlihatkan bentuk program yang bersifat bottom-up. Kondisi berbeda terdapat pada pemuda di kawasan Jalur Pipa dan Sumur J-TB, dimana mereka tidak memiliki kehendak besar untuk mendapatkan CSR, namun tetap menjadi penerima manfaat CSR dengan sifatnya yang top-down, yakni dibawa oleh LSM selaku mitra dari perusahaan.

Aktivitas proyek konstruksi maupun produksi migas yang telah berjalan membawa dampak lingkungan dengan intensitas yang tidak tentu. Dampak lingkungan beberapa kali terjadi terutama dirasakan oleh warga di kawasan ring 1 Sumur Banyuurip. Kebocoran flare adalah salah satu dampak lingkungan yang sering dirasakan warga. Aktivitas pembakaran gas suar bakar (flare) yang tinggi juga berdampak produktivitas pertanian.

Adanya berbagai dampak lingkungan tersebut, memantik serangkaian aksi demonstrasi warga yang diorganisir pemuda, 
terutama di kawasan Sumur Banyuurip. Pemuda Desa Mojodelik telah mengorganisir dua kali aksi demonstrasi untuk menuntut tanggungjawab dari EMCL akibat adanya dampak lingkungan, sedangkan pemuda Desa Gayam juga mengadakan aksi dengan menutup akses jalan menuju Sumur J-TB guna menuntut perbaikan infrastruktur jalan. Aksi itu berangkat dari ide dan inisiatif pemuda, meskipun juga tetap berkoordinasi dengan kepala desa dan camat. Pemuda memandang kepala desa dan camat sebagai sumber otoritas formal pemerintahan yang paling dekat dengan warga desa dan efektif untuk membangun legitimasi atau minimal memberikan ijin untuk digelarnya aksi. Institusi pemerintahan tersebut juga memahami maksud dan tujuan pemuda, sehingga pihak pemerintah desa maupun kecamatan menjadi bundle of power bagi pemuda.

Ikatan kekuatan yang dibentuk oleh aktor pemerintahan nampak tidak sebesar konteks kontrol terhadap akses pekerjaan. Pemuda dalam melakukan kontrol terhadap kondisi lingkungan lebih dapat mengorganisir aksinya. Pemuda tidak hanya menyuarakan kepentingan kelompoknya seperti ketika berupaya melakukan kontrol terhadap akses pekerjaan dan program CSR. Kontrol pemuda digerakkan oleh kepentingan masyarakat desa yang bermula dari persoalan lingkungan. Mengikuti teori akses dari Ribot dan Peluso (2003), adanya bundle of power dengan kepala desa selaku pemegang otoritas formal hanya menjadi salah satu basis, selain itu pemuda juga menggunakan basis kontrol berupa akses pada pengetahuan. Pemuda menggunakan hasil penelitian untuk melakukan kontra wacana yang dikembangkan oleh perusahaan dan pemerintah daerah dalam persoalan terkait dampak flare pada produktivitas tanaman.
Pemuda mampu mengembangkan sikap kritis, melakukan advokasi, dan bertindak sebagai representasi masyarakat (World Youth Report, 2003). Adanya inisiatif pemuda dan kemampuan mengorganisir gerakan menunjukkan pula kontrol dalam konteks participatory governance, dimana pemuda mampu melibatkan diri sebagai masyarakat aktif untuk menyuarakan pandangan, kekhawatiran, dan hak-hak pemuda dan masyarakat (Walker dan Pereznieto, 2014).

Kontrol pemuda terhadap aliran manfaat pekerjaan, program CSR, dan dampak lingkungan berjalan dinamis. Pemuda di satu sisi dapat meraih hasil dari kontrol, namun di sisi lain tidak sedikit menemui hambatan dan tantangan. Hambatan yang dialami pemuda ketika menjalankan kontrol terhadap akses pekerjaan, pertama adalah persoalan kapasitas. Kapasitas ini terkait kompetensi, pengalaman kerja, dan sertifikasi keahlian yang dimiliki pemuda sebagian besar hanya pada pekerjaan kasar atau semiskill. Hambatan pemuda ketika mengakses pekerjaan di proyek J-TB tidak hanya dari sisi kapasitas dan kompetensi. Hambatan kedua memiliki dimensi lebih politis berupa akses pada identitas sosial. Sebagaimana terjadi sebelum proyek EPC Sumur Banyuurip maupun GPF J-TB, identitas sosial menjadi instrumen kontrol untuk menginklusi dan mengeksklusi warga yang dapat mengakses pekerjaan.

Pemuda relatif tidak mengalami hambatan signifikan ketika mengakses program CSR. Adanya kemudahan pemuda untuk mengakses program CSR juga dibentuk dari perubahan sikap perusahaan yang menjadi lebih terbuka dan berupaya mengalirkan manfaat CSR pada berbagai entitas masyarakat. Hambatan dan tantangan bagi pemuda justru muncul ketika 
Danang Wahyuhono, Suryo Purwono, Dyah Mutiarin -- Kontrol Pemuda Terhadap Tata Kelola Migas Dan Implikasinya Pada Ketahanan Wilayah Di Kawasan Migas Blok Cepu Kabupaten Bojonegoro

pelaksanaan program CSR. Beberapa program yang berjalan ada yang tidak bermula dari aspirasi dan gagasan pemuda. Pemuda pada awalnya menerima program yang menyasar kelompoknya, namun dalam pelaksanaannya tidak sinergis dan tidak terjalin komunikasi yang baik dengan LSM pendamping. Program CSR kemudian dianggap tidak efektif oleh pemuda, dan LSM pendamping dinilai pemuda tidak serius dan pragmatis dalam mendampingi pemuda.

Hambatan dan tantangan yang cukup besar dialami pemuda ketika menjalankan kontrol terhadap dampak lingkungan. Hambatan tersebut pertama terkait perbedaan kepentingan antara pemuda dengan warga secara umum. Warga menganggap beras memberikan aliran manfaat yang merata, sehingga tidak menimbulkan kecemburuan antar warga. Kecemburuan berpotensi terjadi ketika kompensasi diwujudkan dalam bentuk infrastruktur pertanian dan beasiswa pendidikan, karena tidak semua warga memiliki aset pertanian dan anak yang akan menempuh pendidik tinggi. Pemuda memandang sebaliknya, yaitu pendidikan dan infrastruktur pertanian berupa irigasi merupakan program yang memiliki manfaat jangka panjang dan sesuai dengan potensi perekonomian desa yang masih terdapat lahan pertanian.

Adanya perbedaan kepentingan tersebut tidak berdampak pada kemunculan konflik fisik. Pemuda dan warga bahkan bersatu dalam dua kali demonstrasi warga Mojodelik untuk menuntut tanggung jawab pihak perusahaan setelah terjadi dampak lingkungan. Kontrol pemuda kemudian menghadapi hambatan dan tantangan berupa resistensi yang diberikan oleh perusahaan, bahkan sebelum demonstrasi berlangsung. Hal ini terlihat dari respon yang dinilai pemuda lamban, walaupun warga telah mengalami berbagai dampak lingkungan. Pemuda menyebut perusahaan sebagai "Yang Maha Exxon" karena kelambanan dalam merespon persoalan lingkungan, namun tidak ada teguran dari pemerintah daerah. Pemuda menilai bahwa perusahaan telah menguasai pemangku kepentingan lain, terutama pemerintah daerah.

Kontrol yang dijalankan pemuda terhadap aliran manfaat dan dampak, di samping menemui hambatan dan tantangan, juga telah membawa hasil. Hasil dari kontrol pemuda dapat dibedakan ke dalam tiga jenis berdasarkan upaya memperolehnya.

Pertama, hasil kontrol yang mudah diperoleh. Upaya pemuda mengontrol aliran program CSR membawa hasil yang mudah diperoleh dan dimanfaatkan oleh pemuda. Ungkapan "desa yang diserang program" menandakan kemudahan pemuda untuk memperoleh program CSR.

Kedua, hasil yang diperoleh melalui upaya keras. Hal ini merupakan hasil kontrol terhadap dampak lingkungan. Program CSR yang diterima masyarakat sebagai bentuk kompensasi dari perusahaan didahului oleh berbagai aksi pemuda dan masyarakat. Perusahaan juga memberikan resistensi terhadap kontrol pemuda.

Ketiga, hasil yang tidak diperoleh secara langsung atau kegagalan dalam memperoleh hasil. Hal ini merupakan hasil kontrol terhadap akses pekerjaan. Upaya pemuda dari kawasan Jalur Pipa dan Sumur Banyuurip untuk mengontrol akses pekerjaan pada proyek J-TB belum menuai hasil. Kondisi ini berbeda dengan hasil yang diperoleh pemuda kawasan J-TB, dimana mereka menggunakan faktor identitas sosial sebagai kekuatan untuk memperoleh hasil. Kegagalan dalam 
memperoleh hasil kontrol juga dialami oleh pemuda yang tidak memiliki bundle of power berupa akses pengetahuan dalam mengontrol pekerjaan.

\section{Implikasi Kontrol Pemuda Pada Ketahanan Wilayah}

Analisis ketahanan wilayah berada pada dimensi proses maupun implikasi. Dimensi proses mengulas ketangguhan dan keuletan pemuda dalam menghadapi AGHT (Sunardi, 1997), sedangkan dimensi implikasi melihat ketangguhan dan keuletan pemuda dalam menjalankan kontrol yang berdampak pada aspek atau gatra ekonomi, sosial, dan lingkungan (Magis, 2010; Boyd dan Folke, 2012; Berkes dan Ross, 2013; Bhamra, 2015), serta keamanan. Keempat aspek tersebut menerima dampak langsung dari kontrol pemuda dalam tata kelola migas.

Kontrol pemuda memperlihatkan ketangguhan dan keuletan dalam menghadapi AGHT kondisi lingkungan. Ketangguhan dan keuletan yang dimulai dari mengindentifikasi persoalan yang dihadapi warga desa, penggunaan riset sebagai basis legitimasi tuntutan, upaya advokasi kepentingan warga yang bersifat praktis seperti beras maupun berjangka panjang berupa irigasi dan sekolah lapangan pertanian, penggunaan media masa dan sosial untuk menyuarakan tuntutan, membangun hubungan baik dengan kepala desa dan camat sebagai basis legitimasi otoritas formal, hingga aksi demonstrasi ribuan warga dan pemblokiran jalan.

Rangkaian ketangguhan dan keuletan pemuda dan warga tersebut memberi peran signifikan bagi upaya perbaikan ketahanan lingkungan kawasan Blok Cepu. Respon yang diberikan pihak perusahaan telah memperlihatkan upaya-upaya perbaikan ketahanan lingkungan, yaitu perbaikan infrastruktur jalan poros kecamatan serta mengakomodasi semua tuntutan warga terkait perbaikan kondisi lingkungan dan sosial, kecuali tuntutan kompensasi beras.

Ketahanan ekonomi terkait erat dengan adanya harapan warga maupun pemuda untuk meraih berkah dan sejahtera di tengah industrialisasi migas. Proyek migas merupakan harapan baru setelah sebagian warga meninggalkan sektor agraris. Harapan itu diadvokasi oleh kebijakan tata kelola migas berupa Perda Konten Lokal. Kebijakan ini banyak dimaknai sebagai penghargaan bagi warga dan guna mencapai ketahanan ekonomi setelah mereka melepas lahan pertaniannya.

Harapan warga sempat terwujud ketika proyek EPC Sumur Banyuurip Blok Cepu berlangsung. Ribuan pemuda lokal terserap dalam berbagai pekerjaan yang sebagian besar merupakan tenaga kerja kasar. Ekonomi kawasan Blok Cepu bergeliat. Berkah yang dinikmati warga tersebut, termasuk pemuda ternyata cukup singkat. Proyek EPC berakhir pada pertengahan 2016 yang mengakibatkan ribuan tenaga kerja diberhentikan. Banyak pemuda lokal dari desa-desa Blok Cepu menjadi pengangguran.

Pemerintah Kabupaten Bojonegoro bukan tidak mengantisipasi adanya fenomena pengangguran. Pemkab sudah merancang program pelatihan keterampilan kerja sejak proyek EPC masih berlangsung. Pelatihan tersebut bertujuan untuk alih profesi, yaitu dari pekerjaan di proyek migas menjadi non-migas. Upaya fasilitasi berbagai pelatihan tersebut tidak otomatis menghilangkan ketergantungan masyarakat pada proyek migas. Pelatihan yang diharapkan oleh pemuda dan masyarakat umum tetap berupa keterampilan terkait kebutuhan proyek migas, namun di sisi 
lain pihak pemerintah daerah berupaya mewujudkan alih profesi angkatan kerja.

Ketahanan ekonomi wilayah di kawasan Blok Cepu secara umum berada dalam kondisi rentan. Kerentanan paling utama dibentuk oleh ketergantungan pada pekerjaan di proyek migas. Ketergantungan pada proyek migas sulit diharapkan keberlanjutannya, karena selain eksploitasi sumber daya alam yang memiliki batasan waktu, sekaligus proyek konstruksi yang menyerap banyak tenaga kerja juga memiliki waktu yang cukup singkat, yaitu hanya ketika persiapan sebelum produksi migas. Adapun berbagai contoh praktik diversifikasi ekonomi seperti wirausaha jamur dan pendirian $\mathrm{CV}$ oleh pemuda belum memperlihatkan bentuk ketahanan ekonomi wilayah secara sistemik. Contoh ketangguhan dan keuletan pemuda tersebut berada pada dimensi agensi, yaitu sebatas untuk kepentingan komunitasnya sendiri namun belum secara menyuluruh bagi ketahanan ekonomi wilayah.

Konteks ketahanan sosial wilayah terkait kondisi dinamis kawasan Blok Cepu. Adanya persoalan lingkungan yang memantik aksi demonstrasi merupakan salah satu tanda dinamika sosial di kawasan tersebut. Dinamika sosial semacam itu telah dirasakan oleh warga dalam kurun waktu yang cukup lama, setidaknya sejak warga menghadapi proses pembebasan lahan dan masa persiapan proyek. Dinamika sosial tidak menurun tatkala proyek dimulai dan menyerap banyak tenaga kerja lokal. Kondisi sosial di permukaan nampak stabil, namun terjadi perubahan sosial di tengah warga, terutama berupa persoalan mulai terkikisnya modal sosial masyarakat seiring membesarnya aliran program CSR yang diberikan perusahaan pada masyarakat. Kontrol sosial pemuda dalam konteks ini belum optimal menjaga ketahanan sosial dalam arti mengurangi ketergantungan dan sikap pragmatis warga dan pemuda. Kawasan Blok Cepu secara umum tidak terdapat konflik yang termanifestasi, namun ketahanan sosial dalam kondisi rentan.

Ketahanan wilayah di kawasan Blok Cepu tidak terpisah dari persoalan keamanan. Ancaman terhadap keamanan wilayah nampak berubah pasca proyek EPC. Ancaman yang muncul pra EPC adalah kekhawatiran jika kepentingan masyarakat lokal tidak terpenuhi, sedangkan pasca EPC adalah dampak turunan dari fenomena pengangguran. Berbagai pihak memiliki pemahaman yang sama bahwa persoalan pengangguran membawa ancaman berupa tindak kriminalitas.

Kekhawatiran warga bahkan muncul ketika proyek EPC masih berlangsung, dimana beberapa pekerja lokal telah melakukan tindak pencurian barang atau perlengkapan proyek seperti besi dan pipa. Kekhawatiran semakin bertambah ketika dikaitkan dengan kebiasaan masyarakat dan perubahan gaya hidup. Kebiasaan berupa "minum" dan berjudi yang kadang masih dilakukan oleh beberapa masyarakat, serta standar hidup yang semakin tinggi ketika menikmati penghasilan dari pekerjaan proyek migas. Gaya hidup dan kebiasaan itu kemudian bertemu dengan kebutuhan sehari-sehari, seperti kebutuhan untuk menghidupi keluarga. Adanya dorongan dan desakan hidup tersebut terbentur dengan sumber penghidupan yang semakin sulit diakses dan dikontrol. Adanya keresahan warga ini menandakan bahwa kondisi ketahanan kemanan di kawasan Blok Cepu masih bersifat rentan.

\section{SIMPULAN}

Penelitian ini memiliki simpulan berupa realitas ketahanan yang heterogen. 
Pertama, adanya heterogenitas ketahanan wilayah, yaitu meskipun sesama berada di kawasan Blok Cepu, namun desa-desa di dalamnya saling berupaya membangun ketahanan wilayahnya sendiri, misalnya dibuktikan melalui upaya berebut kontrol atas akses pekerjaan. Semakin dekat suatu wilayah pada keberadaan sumber daya alam atau tempat beroperasinya proyek migas, maka semakin besar pula daya kontrol. Kontrol yang dipengaruhi oleh kedekatan entitas pada pusat sumber daya tersebut membangun bundle of power berupa akses pada identitas sosial. Pemuda selain menggunakan identitas sosial, juga menggunakan ikatan kekuatan berupa relasi sosial dengan kepala desa dan kontraktor lokal, serta sebagian kecil menggunakan akses pada pengetahuan yang membangun kapasitas pribadi untuk mengakses pekerjaan.

Kedua,adanya heterogenitas antara ketahanan wilayah dengan ketahanan nasional. Logika ketahanan nasional dalam konteks tata kelola sumber daya alam adalah produksi maksimal sumur migas yang kemudian dapat memenuhi kebutuhan energi dan menopang sumber pendapatan nasional. Logika tersebut tidak selalu linier dengan ketahanan wilayah di kawasan penghasil migas, dimana perlu memperhatikan dampak lingkungan dan sosial, serta distribusi aliran manfaat yang optimal agar warga lokal dapat menuai berkah dan tidak berada dalam kondisi rentan di tengah eksploitasi kekayaan alam di desanya.

Penelitian ini memiliki rumusan rekomendasi praksis dan akademis.

Pertama,rekomendasi praksis berangkat dari realitas bahwa pemuda di satu sisi telah menjadi aktor penting dalam konteks tata kelola migas yang berjalan di Blok Cepu, namun di sisi lain juga masih menghadapi hambatan dan tantangan. Hal ini diperlukan langkah strategisberupa peningkatan kapasitas pemuda untuk mengakses pekerjaan di dalam proyek migas maupun membangun keberdayaan tanpa bergantung pada proyek migas. Langkah operasional dalam hal ini berupa:

(1). Peningkatan akses terhadap pendidikan dan pelatihan untuk memperoleh sertifikat atau ijazah yang dapat meningkatkan keahlian dan kompetensi pemuda dalam proyek migas. Pendidikan dan pelatihan tidak hanya mengubah kompetensi pemuda sebagai tenaga kasar menjadi terampil, sekaligus mengubah kompetensi dari tenaga terampil menjadi ahli. Hal ini diperlukan fasilitasi beasiswa pendidikan dan pelatihan yang lebih merata melalui kemitraan antara perusahaan, pemerintah daerah, dan institusi pendidikan kredibel yang memiliki program studi terkait migas.

(2).Revisi Perda Konten Lokal juga diperlukan sebagai rekomendasi atas hambatan dan tantangan berupa identitas sosial. Revisi Perda Konten Lokal diharapkan lebih memperjelas definisi lokal untuk dijadikan dasar pembagian akses terhadap pekerjaan.

(3). Upaya memutus ketergantungan pada pekerjaan proyek migas, dapat dijalankan melalui peningkatan efektivitas program kewirausahaan. Entitas pemuda yang telah memiliki kesadaran dan mampu membangun kewirausahaan dapat memfasilitasi entitas pemuda lainnya yang belum paham dan berdaya untuk menjalankan wirausaha. Upaya memutus ketergantungan juga ditempuh melalui pemberdayaan bagi pemuda dan masyarakat secara umum yang tidak hanya memanfaatkan program CSR, sekaligus sumber daya lain yang lebih berkelanjutan, seperti APB Desa.

Kedua, rekomendasi akademis dari penelitian ini adalah perlunya agenda 
Danang Wahyuhono, Suryo Purwono, Dyah Mutiarin -- Kontrol Pemuda Terhadap Tata Kelola Migas Dan Implikasinya Pada Ketahanan Wilayah Di Kawasan Migas Blok Cepu Kabupaten Bojonegoro

penelitian yang secara mendalam melihat realitas heterogen dari ketahanan. Ketahanan wilayah bukan merupakan realitas tunggal atau homogen, karena melibatkan berbagai entitas atau pemangku kepentingan dalam suatu wilayah yang sangat memungkinkan saling berebut kontrol guna mencapai ketahanannya sendiri. Ketahanan wilayah dan nasional yang juga memungkinkan memiliki nalar dan kepentingan yang berbeda. Adanya agenda penelitian tindak lanjut dapat mengkonstruksi kembali konsep ketahanan nasional maupun wilayah di tengah realitas dan kepentingan yang beragam antar wilayah di era otonomi daerah dan desa ini.

\section{DAFTAR PUSTAKA}

Berkes, Fikret and Helen Ross, 2013, Community Resilience: Toward in Integrated Approach, Society \& Natural Resources An International Journal26: 5-20, London \& New York : Routledge Taylor \& Francis Group.

Bhamra, Anshul S, 2015, Resilience Framework For Measuring Development, Brief For GSDR 2015

Bojonegoro Institute, $2016<h t t p: / / b i . o r . i d / w p-$ content/uploads/2016/08/Potensi-Migas. png $>$ (diakses 13 Juni 2017)

Boyd, Emily and Carl Folke(eds), 2012, Adapting Institutions: Governance, Complexity and Social-Ecological Resilience, Cambridge: Cambridge University Pres.

Disnakertransos/Disperinaker Kab. Bojonegoro, 2017, Angka Pengangguran di Kabupaten Bojonegoro 2014-2017

Huda, Muhammad Nurul, 2011, "Pentrasi Kapitalisme dan Transformasi Sosial di Bojonegoro: Studi Kasus Proyek Migas Blok Cepu", Tesis: Universitas Indonesia.
Humphreys, Macartan, Jefrey D. Sachs, Joseph E. Stiglitz (eds), 2007, Escaping The Resouce Curse: Berkelit dari Kutukan Sumberdaya Alam (terjemahan), Bogor: The Samdhana Institute.

Jati, Gentur Putro, 2015,https:// www.cnnindonesia.com/ ekonomi/20150319190054-85-40424/ pemerintah-gantungkan-target-produksiminyak-dari-blok-cepu(diakses 25 Januari 2017)

Magis, Kristen, 2010, Community Resilience: An Indicator of Social Sustainability, Society \& Natural Resources, 23: 401-416, London \& New York : Routledge Taylor \& Francis Group.

Radar Bojonegoro, 2016, <https://www. jawapos.com/radarbojonegoro/archive/ read/2016/07/21/2200/masyarakat-blorabelum-terima-dbh-migas-blok-cepu-skkmigas-belum-beri-solusi> (diakses 5 Juli 2017)

Ribbot, Jesse C and Nancy Lee Peluso, 2003, A Theory of Acces, Rural Socilogy Vol.68, No.2, June 2003.

Ross, Michael L, 2007, Bagaimana Negaranegara Kaya Mineral Dapat Mengurangi Ketidakadilan, Escaping The Resouce Curse: Berkelit dari Kutukan Sumberdaya Alam (terjemahan), diedit oleh Humphreys, Macartan, Jefrey D.Sachs, Joseph E. Stiglitz, Bogor: The Samdhana Institute

Sunardi, 1997, Teori Ketahanan Nasional, Jakarta: Hastanas.

Tabloid Blok Bojonegoro Edisi Februari 2015 Walker, David, and Paola Pereznieto, 2014, Partners for Change: Young People and Governance in a Post 2015 World, London: Overseas Development Institute. 
Jurnal Ketahanan Nasional, Vol. 25, No. 1, April 2019: 1-14

World Youth Report, 2003, Youth Participation in Decision Making

\section{Peraturan Perundangan}

Instruksi Presiden Nomor 2 Tahun 2012 Tentang Peningkatan Minyak Bumi Nasional
Peraturan Daerah Nomor 23 Tahun 2011 Tentang Percepatan Pertumbuhan Ekonomi Daerah Dalam Pelaksanaan Eksplorasi Dan Eksploitasi Serta Pengolahan Minyak Dan Gas Bumi Di Kabupaten Bojonegoro.

Wawancara:

Sopri, pemuda Desa Bandungrejo/pekerja 